\title{
A Case Report of Atypical Scrotal Leiomyoma
}

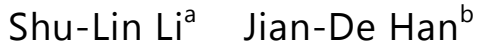 \\ a'Dermatology Department, Zhongshan Urological Hospital of Shenzhen, Shenzhen, and \\ bepartment of Dermatology, The First Affiliated Hospital of Sun Yat-sen Hospital, \\ Guangzhou, China
}

\section{Key Words}

Leiomyoma of the scrotum · Actin · S100

\begin{abstract}
Scrotal leiomyoma is a benign tumor derived from the scrotal dartos muscle; it is rare in clinical findings. The cause of the disease is not yet clear. Here, we present the case of a patient with no typical clinical features, but with some typical pathological changes. A middle-aged male patient saw a doctor for paroxysmal itching and burning of the scrotum. The physical examination revealed $3 \times 5-\mathrm{cm}^{2}$, ill-defined, pink plaques, an uneven surface, and basal infiltration with pigmentation defects in the center. Pathology results showed dermal spindle cells in nodular hyperplasia. The nucleus was round at both ends, a perinuclear halo could be seen, and staining was positive for actin and negative for S100. Therefore, the diagnosis of scrotal myoma was made.

(c) 2013 S. Karger AG, Basel
\end{abstract}

\section{Case Report}

A 32-year-old man presented with a lump on the right side of his scrotum without any predisposing factors. The lump had been progressively growing in size over the last 3 years. Early on, there were 4-5 soybean-shaped, gray and black, flat wart bands with clustered distribution without exudation and desquamation; however, there was paroxysmal itching or the sensation of ants crawling on the skin. The patient often felt his skin was burning and tingling when the itching was very severe. He self-medicated with Compound Dexamethasone Acetate cream, Xuanshi solution, and other medications for external use. After such treatment, the itching eased but the rashes slowly expanded. After drinking or using hot water to clean the areas, the urticant ache became worse each time. He had used some medicine containing hydrochloric acid 1 year previously. Then, the topical skin developed 
ulcers. After the patient took cephalosporin antibiotics, the wound healed and the warts became flat, but the primary sense still remained. To confirm the diagnosis, he visited the hospital. There was no similar history or genetic diseases in his family.

A physical examination revealed no special abnormalities. A more in-depth examination revealed an approximately $3 \times 5-\mathrm{cm}^{2}$, pink, ill-defined, hyperplastic plaque with an uneven surface, basal infiltration, sheet depigmentation in the center (fig. 1), and nearly superficial lymph nodes without palpable enlargement.

The skin biopsy showed dermal spindle cells in nodular hyperplasia. The nucleus was round at both ends, a perinuclear halo could be seen, and staining was positive for actin and negative for S100. The combination of HE morphology, immunohistochemistry, and pathology was in line with a diagnosis of scrotal leiomyoma (fig. 2, fig. 3, fig. 4).

\section{Discussion}

Leiomyomas are benign soft tissue neoplasms that arise from smooth muscle. In this case, the skin leiomyoma came from the hair erector muscles of the skin, dartos, and blood vessel walls of smooth muscle. This type of cancer is generally divided into 3 subtypes: vascular, genital, and hair leiomyoma. Genital leiomyoma involves the smooth muscle network from the deep dermis such as the scrotal dartos muscle [1]. Cutaneous leiomyomas account for approximately $5 \%$ of all leiomyomas, and genital smooth muscle tumors, such as scrotal leiomyoma, have an even lower clinical incidence rate. Europe, the United States, Japan, and some Southeast Asian countries have reported a few cases in recent years [2, 3]. So far, just 3 cases have been reported in our country.

The pathogenesis of the disease is not yet clear, though some scholars have proposed the disease may be related to the male hormone androgen, and experiments have confirmed that the lesions demonstrate androgen receptor expression [4]. Leiomyoma is known to occur in the uterus; however, levels of the female hormones estrogen and progesterone are closely related to scrotal leiomyoma in male endocrine and metabolic disorders, genetic mutation, or immune abnormalities. To confirm this, further study is needed.

The disease often occurs in white males aged 40-60 years [5]. Clinically, it often manifests as solitary tumors showing slow growth [6]. Usually, there are no early symptoms; however, over the course of time, the paroxysmal pain increases. Our patient, who had local lesions, experienced paroxysmal severe itching with burning, tingling, and, as mentioned in the previous literature reports, no pain or bursts of pain. The pain is thought to be due to the smooth muscle contraction, but the itching is difficult to explain. Pathology showed there was no obvious inflammatory cell infiltration.

The clinical manifestations of scrotal leiomyoma may not be characteristic of the disease, and in order to identify it, a variety of differential diagnoses are needed including dermatofibroma, schwannoma, neurofibroma, adnexal tumors, and metastases (table 1). The most important thing is to rely on the pathology-based and differential diagnoses. The histopathological features of the disease are the proliferation of tumor cells with characteristics of smooth muscles cells and actin-positive immunohistochemistry. Therefore, our patient's diagnosis was clear. Most leiomyoma lesions are benign and complete resection of the tumor, such as with Mohs micrographic surgical technique, rather than with radiotherapy treatment, is advised because radiotherapy treatment may induce malignant transformation [7]. 
Li et al.: A Case Report of Atypical Scrotal Leiomyoma

\section{References}

1 Spencer JM, Amonette RA: Tumors with smooth muscle differentiation. Dermatol Surg 1996;22:761-768.

-2 Kato Y, Hori J, Taniguchi N, et al: Solitary genital leiomyoma of the tunica dartos: a case report and review of the literature in Japan (in Japanese). Hinyokika Kiyo 2005;51:699-701.

3 Philip J, Manikandan R, Vishwanathan P, et al: Symplastic scrotal leiomyoma: a case report. J Med Case Reports 2008;2:295.

4 Suárez-Peñaranda JM, Vieites B, Evgenyeva E, et al: Male genital leiomyomas showing androgen receptor expression. J Cutan Pathol 2007;34:946-949.

5 Chiong E, Tan KB, Siew E, et al: Uncommon benign intrascrotal tumours. Ann Acad Med Singapore 2004;33:351-355.

6 Siegal GP, Gaffey TA: Solitary leiomyomas arising from the tunica dartos scroti. J Urol 1976;116:69-71.

7 Sherwani RK, Rahman K, Akhtar K, et al: Leiomyoma of scrotum. Indian J Pathol Microbiol 2008;51:72-73.

Table 1. Differential diagnoses

\begin{tabular}{|c|c|c|c|}
\hline $\begin{array}{l}\text { Differential } \\
\text { diagnosis }\end{array}$ & Vulnerable population & Clinical manifestation/clinical feature & Histopathological findings \\
\hline Neurofibroma & $\begin{array}{l}\text { Higher prevalence in } \\
\text { adults. Cases in } \\
\text { children occur less } \\
\text { frequently }\end{array}$ & $\begin{array}{l}\text { A single, protruding, rounded, epidermal } \\
\text { nodular or fusiform/both hard and soft in } \\
\text { quality }\end{array}$ & $\begin{array}{l}\text { S-shaped cell nucleus, thin fibers, rippled } \\
\text { wall; S100 and neurofilament immunoreac- } \\
\text { tivity are positive }\end{array}$ \\
\hline Neurilemmoma & $\begin{array}{l}\text { All ages and both } \\
\text { genders can be } \\
\text { affected }\end{array}$ & $\begin{array}{l}\text { Often occurs in the limbs, especially on the side } \\
\text { of the large nerve flexor/tumors are a scattered } \\
\text { soft mass, usually without symptoms }\end{array}$ & $\begin{array}{l}\text { Microscopically, the Schwann cells are } \\
\text { arranged bundles or evacuation strips; can } \\
\text { have a lobulated or vortex structure. } \\
\text { S100 protein, corrugated fiber protein, and } \\
\text { myelin basic protein-positive staining }\end{array}$ \\
\hline Dermatofibroma & $\begin{array}{l}\text { May occur at any age, } \\
\text { but more commonly } \\
\text { in young patients. } \\
\text { Female patients } \\
\text { outnumber males }\end{array}$ & $\begin{array}{l}\text { In the upper torso, axilla, upper arm, or } \\
\text { neck/brown or reddish skin papules or nodules } \\
\text { Fitzpatrick's sign ('concave nest' or } \\
\text { dimple sign) }\end{array}$ & $\begin{array}{l}\text { Fasciculated spindle cells are plaque-like } \\
\text { hyperplasia in intradermal, collagen fiber } \\
\text { hyperplasia; fusiform eosinophilic } \\
\text { cytoplasm lightly stained }\end{array}$ \\
\hline $\begin{array}{l}\text { Dermatofibro- } \\
\text { sarcoma } \\
\text { protuberans }\end{array}$ & $\begin{array}{l}\text { Common in middle- } \\
\text { age, with a slight male } \\
\text { proclivity }\end{array}$ & $\begin{array}{l}\text { May occur on the chest; limbs common/raised, } \\
\text { hardened lumps, on which there are multiple } \\
\text { nodules; pink or purple. Lesions gradually } \\
\text { increase and integrate, the surface is slightly } \\
\text { glossy; slow growth }\end{array}$ & $\begin{array}{l}\text { Spindle cells arranged in wheel- or spiral- } \\
\text { shaped pattern, mild atypical changes, CD34 } \\
\text { positive }\end{array}$ \\
\hline Leiomyosarcoma & $\begin{array}{l}\text { Most common in } \\
\text { elderly patients, also } \\
\text { occurs in the young. } \\
\text { Rarely seen in } \\
\text { children }\end{array}$ & $\begin{array}{l}\text { The most common location is the retroperitone- } \\
\text { al area. Larger tumors are more common in } \\
\text { females/hardened nodules occur in the skin can } \\
\text { be multilobed, often slightly elevated, can invade } \\
\text { the dermis and cause atrophy and ulceration }\end{array}$ & $\begin{array}{l}\text { The tumor is composed of spindle cells } \\
\text { staggered into a bundle. Elongated, blunt- } \\
\text { ended nuclei. Various cell sizes, a lot of } \\
\text { cellular constituent, and nuclear mitosis }\end{array}$ \\
\hline $\begin{array}{l}\text { Smooth muscle } \\
\text { hamartoma }\end{array}$ & $\begin{array}{l}\text { Occurs at birth, in } \\
\text { young children and } \\
\text { adolescents }\end{array}$ & $\begin{array}{l}\text { Occurs on the waist/in patches, up to a few } \mathrm{cm} \text {, } \\
\text { or can be raised with small follicular papules }\end{array}$ & $\begin{array}{l}\text { Throughout the dermis and subcutaneous } \\
\text { tissue there are numerous, scattered, } \\
\text { straight and long smooth muscle fiber } \\
\text { bundles, with two nearly rounded ends, } \\
\text { consistent with the long axis of the muscle } \\
\text { fibers and the long axis of the core, which } \\
\text { interlace }\end{array}$ \\
\hline
\end{tabular}




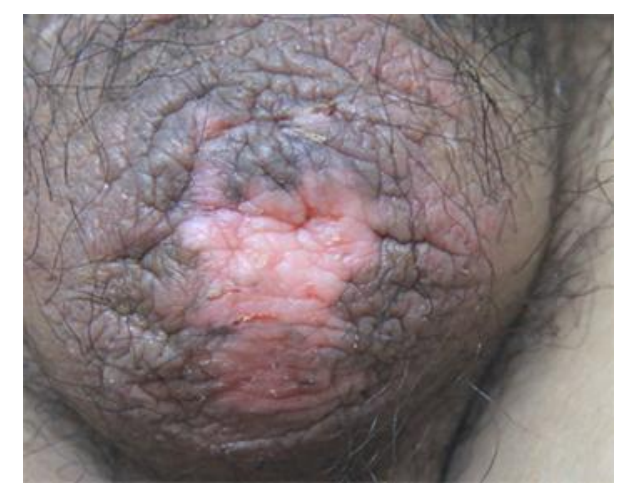

Fig. 1. Pink, hyperplastic plaques, with an uneven surface, basal infiltration, and ill-defined, sheet depigmentation in the center.

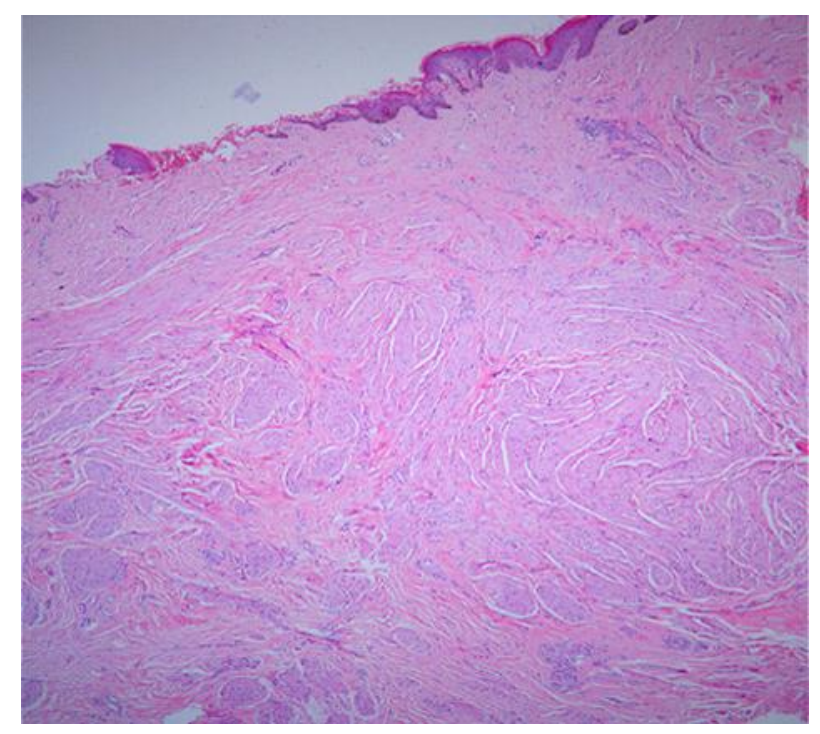

Fig. 2. Spindle tumor cells of nodular hyperplasia, arranged in an interwoven pattern. HE. $\times 100$. 


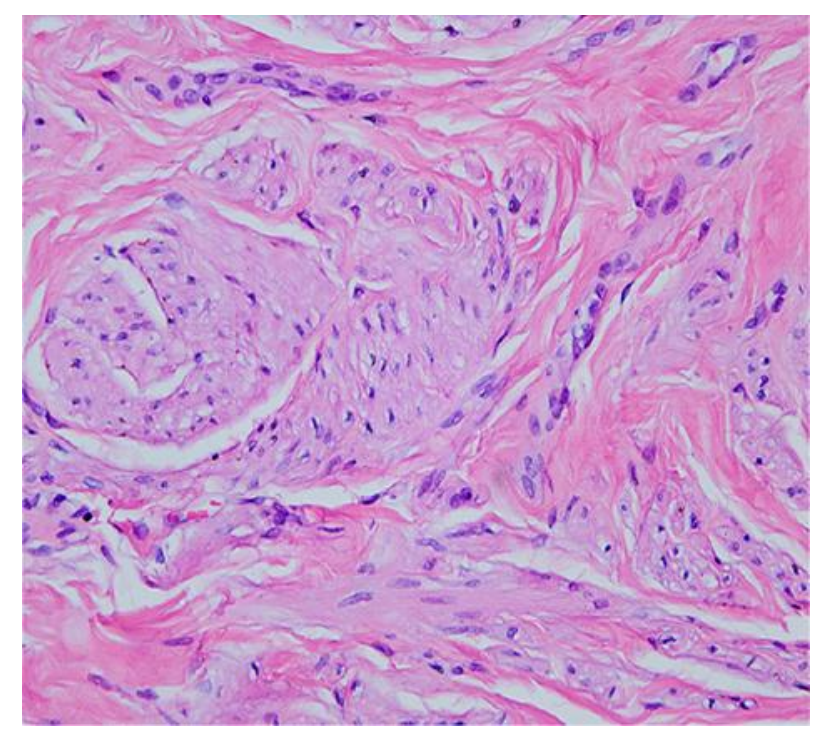

Fig. 3. Classic spindle-shaped tumor cells, abundant cytoplasm, and hyperplasia of fibroblasts in the dermis fibroblasts. HE. $\times 400$.

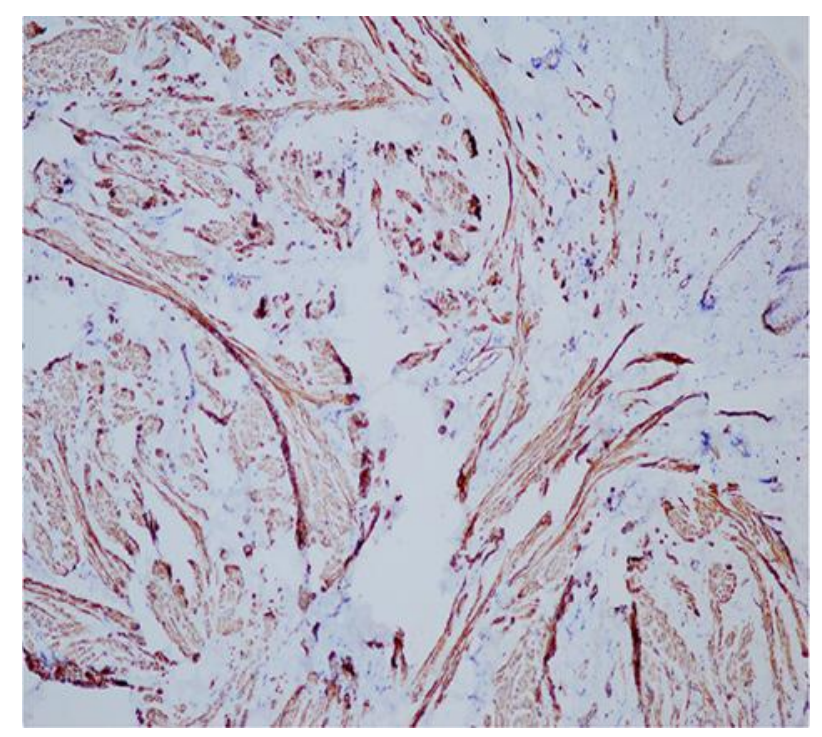

Fig. 4. Actin-positive immunohistochemistry. $\times 100$. 